\title{
LIFELONG LANGUAGE LEARNING IN EUROPE: POSSIBILITIES AND CHALLENGES
}

\author{
Ingrida Žindžiuvienè \\ Austė Sruogaitė-Kuliešienè \\ Vytautas Magnus University, Kaunas
}

\begin{abstract}
Recent demographic changes in Europe (ageing, migration and others) demonstrate the importance of senior adult education - an urgent issue at both national and European Union policy levels. The problem of the research is grounded in the challenges that many European societies currently face: the retirement age being extended, employees need to adapt to the changed working conditions and satisfy urgent demands of the market. The aim of this research is to examine the current situation of senior adult language education in the EU. The research objectives question one of the basic needs faced by senior citizens - to acquire or maintain multilingual skills, without which their status in the competitive market would become complicated. In many European countries, senior adult education is viewed as an integral part of the whole education system that is directed towards engagement of senior citizens into active social life, job maintenance, development of cross-cultural communicative and language skills and more diverse opportunities for self-realization.
\end{abstract}

Keywords: competitive market, demographic changes, legislation system, lifelong language learning, senior adult education

\section{Introduction}

Globalization, technological advance, increased mobility among the European Union Member States and ageing populations are the factors that have significantly changed the European language policy and received unprecedented attention from the EU institutions. According to the European Commission, "A successful multilingualism policy can strengthen life chances of citizens: it may increase their employability, facilitate access to services and rights and contribute to solidarity through enhanced intercultural dialogue and social cohesion" (Multilingualism: An Asset for Europe and a Shared Commitment, 2008: 3). As stated in the documents of the European Association for the Education of Adults (2006), "Adult education is needed to help keep them active in the workforce longer, and to be able to live an active and rewarding life in retirement as engaged citizens" (Adult Education Trends and Issues in Europe, 2006: 2). Thus, the recent attention to lifelong learning and development of multilingualism, and the demographic and social changes in Europe were the main reasons for the examination of current situation of senior adult language education in the EU. The following factors were taken into account: trends of adult education in the EU, characteristics of senior learners, the scope of participation in adult education and language policy in Europe. 


\section{Trends of Adult Education in Europe}

As stated by Margarita Teresevičienè and Vaiva Zuzevičiūtè (2009), "Changes that occurred in the $20^{\text {th }}$ century influenced the view towards the concept of education", so that "the changing profile of European inhabitants, i.e. longer lifespan, declining birth rates and a large number of older people in the population, is one of the most relevant aspects of change in Europe" (Teresevičienè and Zuzevičiūtè, 2009: 39). Thus, recent demographic changes in Europe, especially ageing and migration, have resulted in the extension of retirement age in the Member States of the European Union. These factors have significantly changed the concept of education at both national and European Union policy levels.

The European Association for the Education of Adults (2006) distinguishes several aspects that influence current situation of adult education in Europe, i.e. (1) legislation and financial systems, (2) trends in participation, (3) ageing and (4) migration. According to the statements provided by the European Association for the Education of Adults, it is determined that "adult education is more institutionalised and firmly structured in the northern and western nations of Europe. [...] In the southern and eastern countries various different bodies and social structures tend to supply the impetus, and adult learning often takes place in work or other social settings, rather than in specific institutions" (Adult Education Trends and Issues in Europe, 2006: 13). Such situation explains the fragmented "political responsibility" in most countries (Ibid.)

Despite differences in adult education policies in European countries, regulations related to adult education exist in all the European Union Member States. Following the classification proposed by the European Association for the Education of Adults, regulations of adult education tend to fall into four major categories: (1) Regulations offering public financial support to providers of adult education - this type is supply-based and is more common in countries with a well-developed institutional structure of adult education; (2) Regulations establishing individual entitlements to educational leave - this type may have different financial implications for either the employee taking the leave or the employer when, normally, the learner decides which course to attend; (3) Regulations offering financial incentives to learners to take part in education: for example, co-financing schemes. (4) Regulations establishing a framework for the recognition of prior, non-formal and informal learning (Adult Education Trends and Issues in Europe, 2006: 14). Different types of regulations show that adult learning is an important part of education policy in Europe. However, often responsibility for adult learning is attributed to separate individuals and non-governmental providers - this can be considered as the main reason for limited financial support from the state. 
The level of participation in adult education can be different in distinct European Union countries; however, some general characteristics of the participation in adult education can be determined: for example, the participation in adult learning declines with age; a complicated social situation of a particular country can restrict the participation in adult education; participation is lower in rural than in urban areas; ethnic minorities take a considerably less active part in adult learning than the native population, etc. (Adult Education Trends and Issues in Europe, 2006:23).

The major obstacles to the participation in adult education "may be of a practical kind - lack of time, money, appropriate educational offers, or of a socialpsychological order - unsupportive social environment among friends, family, and superiors, lack of learning culture, bad previous learning experience, failure to perceive the benefits of learning, and so on" (Adult Education Trends and Issues in Europe, 2006: 23). European institutions develop various programs and documents related to lifelong learning. For example, the strategic framework for European cooperation in education and training adopted in May 2009 sets a number of benchmarks to be achieved by 2020, including one for lifelong learning, namely that an average of at least $15 \%$ of adults aged 25 to 64 years old should participate in lifelong learning (Eurostat, 2010). However, in 2009, the proportion of persons aged 25 to 64 in the EU receiving some form of education or training in the four weeks preceding the labour force survey was $9.3 \%$ (Eurostat, 2010).

Demographic changes such as decreased birth-rate, rising life expectancy and a larger group of older population have a significant impact on life quality and living conditions in Europe. As stated by the European Association for the Education of Adults, "This new demography has far-reaching consequences as there are fewer employees to pay taxes and more retired people draw pensions and use health, nursing and related services more heavily. A health budget or "care for the elderly crisis' loom in many countries" (Adult Education Trends and Issues in Europe, 2006: 34). Adult education has to compete with other public sectors such as health or welfare for public expenditure; therefore it becomes necessary to keep senior citizens active and employed for a longer period of time.

Migration is another factor that has a direct influence on adult education in Europe. The European Association for the Education of Adults describes the implications of migration as follows, "It is not as simple as the incoming migrants filling the holes in the labour market left by the ageing workforce. The implications for adult learning and education are massive. New residents require knowledge and skills to manage in their new country, even with high skills on entry" (Adult Education Trends and Issues in Europe, 2006: 34-35).

Thus, existing inadequacies in national adult education policies throughout Europe, low financial support from the state, demographic changes, migration 
and personal obstacles to the participation in adult education, e.g. lack of time, money, appropriate educational offers, unsupportive social environment among friends, family, and superiors, etc., are the main factors that restrict successful development of adult education in Europe.

\section{Characteristics of Senior Learners}

Following the statements provided by the European Commission in Grundtvig 1.1. - Lifelong Learning Programme (Language Course Teaching Methods for Senior Citizens, 2006: 5), senior learners can be described in accordance with three age categories: (1) from 58 to 64 years; (2) from 65 to 74 years; (3) over 74 years. Individual ageing depends on many factors different of the age, for example the personal history or other variables like sex, social class, different levels of self-esteem, or amount and quality of relations entertained, perception of the one's usefulness and independence" (Language Course Teaching Methods for Senior Citizens, 2006: 5). According to Teresevičienė and Zuzevičiūtè, "The exact time when one reaches old age depends on their social age: the younger and less wealthy consider 55 years to be the start of old age; meanwhile older and richer people consider 65 years to mark senior age" (Teresevičienė and Zuzevičiūtè, 2009: 69, emphasis added).

Consequently, considering propositions for lifelong learning, senior learners can be divided into three age groups: from 55-65 years (citizens still actively contributing to the society); from 65-75 (citizens, whose ambitions depend on their health, professional status and personal relations); and 75 years and older (citizens, who begin to rest and tend to withdraw from an active social life). The European Association for the Education of Adults (2006) emphasizes the fact that the concept and situation of senior citizens is changing due to educational, cultural and personal factors (Adult Education Trends and Issues in Europe, 2006: 38). Altered attitudes towards senior citizens may encourage policymakers to reconsider national and international directions of lifelong learning and to ensure more possibilities for senior citizens to participate in adult education; while senior learners in turn are responsible for newly acquired possibilities for self-development.

\section{Major Determinants of Adult Education in Europe}

Lifelong learning is a concept that has received unprecedented attention from European authorities and scholars. As observed by Margarita Teresevičienè and Vaiva Zuzevičiūte (2009), the concept of lifelong learning "has become part of daily, not just political or scholarly, discourse" (Teresevičienè and Zuzevičiūtè, 2009: 7). Today, when multilingualism becomes one of the topical issues in the European Union and one of the most important competences for the $21^{\text {st }}$-century 
citizen, lifelong language learning (LLL) turns into an urgent direction that emphasizes the importance of foreign language education for adults. According to William Aitchinson (2004), "the language training given at school is clearly not enough: each one of us will need, over the years, to improve his or her skills, learning new languages or deepening our knowledge of a given foreign language. Language learning, in short, will have to become a lifelong activity" (Aitchinson, 2004: 19, emphasis added).

Understanding the importance of lifelong learning, various investigations related to adult education can reveal relevant information which can help to improve adult education in Europe. Table 1 and Table 2 demonstrate reasons and obstacles to the participation in adult education and training in Baltic region countries.

Table 1

Reasons for the participation in non-formal education and training

(Adapted from the records provided by Eurostat, 2007b)

\begin{tabular}{|c|c|c|c|c|c|c|c|c|c|}
\hline & $\begin{array}{c}\text { To get } \\
\text { knowled- } \\
\text { ge/ } \\
\text { skills } \\
\text { relating to } \\
\text { interestin } \\
\text { g subjects }\end{array}$ & $\begin{array}{c}\text { To get } \\
\text { knowled- } \\
\text { ge/ } \\
\text { skills } \\
\text { useful for } \\
\text { everyday } \\
\text { life }\end{array}$ & $\begin{array}{c}\text { To } \\
\text { increase } \\
\text { possibili } \\
\text { ty of } \\
\text { getting/ } \\
\text { chan- } \\
\text { ging job }\end{array}$ & $\begin{array}{c}\text { Oblige } \\
\text { d to } \\
\text { partici } \\
\text {-pate }\end{array}$ & $\begin{array}{c}\text { To } \\
\text { be } \\
\text { less } \\
\text { like- } \\
\text { ly to } \\
\text { lose } \\
\text { job }\end{array}$ & $\begin{array}{c}\text { Do job } \\
\text { better/ } \\
\text { impro } \\
\text { ve } \\
\text { career } \\
\text { pro- } \\
\text { spects }\end{array}$ & $\begin{array}{c}\text { Meet } \\
\text { new } \\
\text { people } \\
\text { for fun }\end{array}$ & $\begin{array}{c}\text { Obtain } \\
\text { qualifi } \\
\text {-cation }\end{array}$ & $\begin{array}{c}\text { Start } \\
\text { own } \\
\text { busi- } \\
\text { ness }\end{array}$ \\
\hline $\begin{array}{c}\text { Denmar } \\
\text { k }\end{array}$ & 90.3 & 63.5 & 9.4 & 38.7 & 16.9 & 86.6 & 44.5 & 27.0 & 2.2 \\
\hline Estonia & 21.1 & 17.6 & 5.8 & 24.9 & 15.1 & 80.2 & 2.4 & 8.8 & 1.6 \\
\hline Finland & 62.1 & 41.1 & 16.1 & 35.3 & 14.3 & 69.1 & 30.0 & 13.5 & 3.7 \\
\hline $\begin{array}{c}\text { German } \\
\text { y }\end{array}$ & 45.9 & 14.3 & 15.6 & 25.0 & 19.9 & 68.0 & 10.5 & 11.6 & 3.8 \\
\hline Latvia & 43.8 & 58.6 & 17.8 & 33.7 & 27.7 & 74.7 & 24.3 & 37.8 & 4.4 \\
\hline $\begin{array}{c}\text { Lithuani } \\
\text { a }\end{array}$ & 50.6 & 42.3 & 17.5 & 26.2 & 31.3 & 77.5 & 11.8 & 41.4 & 3.4 \\
\hline Norway & 67.9 & 33.2 & 9.6 & 43.1 & 12.7 & 71.8 & 16.0 & 18.3 & 1.5 \\
\hline Poland & 7.6 & 7.2 & 7.2 & 5.2 & 6.6 & 67.1 & 0.5 & 7.2 & 1.4 \\
\hline Sweden & 59.3 & 41.8 & 6.5 & 36.4 & 8.0 & 61.8 & 20.8 & 8.9 & 1.5 \\
\hline
\end{tabular}

The analysis of the reasons for adult education in the Baltic region shows that the main reasons for the participation in non-formal adult education in the majority of Baltic region countries are doing job better, improving career prospects and acquiring knowledge and skills related to interesting and useful subjects.

The main obstacles to the participation in adult education and training in the majority of Baltic region countries are conflict with work schedule, high cost of adult education, not having time due to family responsibilities and no educational institutions within reachable distance (See Table 2). 


\section{Obstacles to the participation in adult education and training}

Table 2

(Adapted from the records provided by Eurostat, 2007a)

\begin{tabular}{|c|c|c|c|c|c|c|c|c|}
\hline & $\begin{array}{c}\text { Health } \\
\text { or age }\end{array}$ & $\begin{array}{c}\text { None } \\
\text { within } \\
\text { reachable } \\
\text { distance }\end{array}$ & $\begin{array}{c}\text { No } \\
\text { time } \\
\text { due to } \\
\text { family }\end{array}$ & $\begin{array}{c}\text { Did not } \\
\text { have the } \\
\text { prerequi } \\
\text { sites }\end{array}$ & $\begin{array}{c}\text { Too } \\
\text { expensive } \\
\text { could not } \\
\text { afford }\end{array}$ & $\begin{array}{c}\text { Did not } \\
\text { like idea } \\
\text { of going } \\
\text { back to } \\
\text { school }\end{array}$ & $\begin{array}{c}\text { Lack of } \\
\text { employer } \\
\text { support }\end{array}$ & $\begin{array}{c}\text { Conflict } \\
\text { with } \\
\text { work } \\
\text { schedule }\end{array}$ \\
\hline Estonia & 17.1 & 32.5 & 36.6 & 2.7 & 50.1 & 8.0 & 8.4 & 30.8 \\
\hline Finland & 16.6 & 24.7 & 30.0 & 11.2 & 21.5 & 6.9 & 23.3 & 42.3 \\
\hline Germany & 10.4 & 21.3 & 29.1 & 20.6 & 37.4 & 9.5 & 28.1 & 31.6 \\
\hline Latvia & 11.9 & 24.1 & 40.1 & 11.2 & 50.8 & 11.9 & 29.7 & 36.8 \\
\hline Lithuania & 13.2 & 19.6 & 34.2 & 3.2 & 45.6 & 4.9 & 16.2 & 48.4 \\
\hline Norway & 19.2 & 13.3 & 25.4 & 4.2 & 17.3 & 9.0 & 20.8 & 31.7 \\
\hline Poland & 9.1 & 31.0 & 29.2 & 9.2 & 61.3 & 17.5 & 20.4 & 31.4 \\
\hline Sweden & 22.9 & 21.2 & 22.2 & 5.6 & 31.4 & 6.7 & 18.4 & 31.3 \\
\hline
\end{tabular}

As observed by the TNS Opinion \& Social, "The European Union population, like those of most other world regions, is living longer and in better health" (TNS Opinion \& Social, 2012: 3). However, fast ageing of European population is often considered as a threat instead of one of the greatest European achievements. Thus, senior citizens' attitudes, self-confidence and willingness to contribute as active members of the contemporary society are considered as significant factors for the implementation of the European policy of social integration. In accordance with the records provided by the International Research Coordination Centre TNS Opinion \& Social, "across the 27 Member States the average age at which someone reaches "old age" is felt to be 63.9 years" (TNS Opinion \& Social, 2012: 10). The analysis of the European citizens' understanding of age shows that $33 \%$ of the respondents think that the age when one starts to be regarded as "old" ranges from 61 to 70 years. $24 \%$ of the European citizens think that "old" age starts from 51 to 60 years, while $16 \%$ of the respondents state that "old" age starts from 71 to 80 years. The opinion of Lithuanian citizens is not significantly different from other European Union Member States. The Lithuanians consider that a person starts to be regarded as "old" when s/he becomes 65.3 years old (See Table 3, the names of Baltic region countries are highlighted).

In addition, the analysis of Baltic region countries shows that the youngest age when one starts to be regarded as "old" is in Germany (60.1 years), Latvia (61.5 years), Estonia (62.4 years) and Poland (62.8), while the "old" age in Denmark, Lithuania, Finland and Sweden ranges from 64.3 to 66.6 years. 
Table 3

European citizens' understanding of age (self-perception of being old) (the EU Member States) (Adapted from the records provided by TNS Opinion \& Social, 2012)

\begin{tabular}{|c|c|c|c|c|c|}
\hline BE & 67.9 & FR & 65.9 & AT & 61.9 \\
\hline BG & 63.8 & IT & 67.6 & PL & 62.8 \\
\hline $\mathbf{C Z}$ & 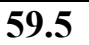 & CY & 68.5 & PT & 67.9 \\
\hline DK & 64.3 & LV & 61.5 & RO & 60.5 \\
\hline DE & 60.1 & LT & 65.3 & SI & 66.4 \\
\hline $\mathbf{E E}$ & 62.4 & $\mathbf{L U}$ & 63.7 & SK & 57.7 \\
\hline IE & 64.2 & HU & 58 & FI & 65.2 \\
\hline EL & 65.7 & MT & 65.2 & SE & 66.6 \\
\hline ES & 65.5 & NL & 70.4 & UK & 61.9 \\
\hline
\end{tabular}

Motivation of senior citizens is a significant factor in adult education; however, it is strongly related to the senior citizens' self-concept, self-esteem and their attitude to lifelong learning in general. Two key aspects should be considered when analysing motivation in adult education, i.e. what are the stimuli for lifelong learning and what subjects are the most interesting and necessary for senior learners. The research data (provided by "Lietuvos suaugusiųjų švietimo ir informavimo centras" (The Lithuanian Adult Education and Information Centre) (2009) and "Socialinès informacijos ir mokymų agentūra" (The Agency of Social Information and Education) (2011)) demonstrates that the main reasons motivating seniors to participate in adult education are higher requirements in labour market, opportunities for self-realization, increased possibilities of finding a job and motivation to meet new people.

The survey of Lithuanian research on educational preferences of adult learners shows that foreign language learning remained one of the most interesting and necessary subjects for adult learners during the period of 2003-2011. Different other fields such as literature, tourism, religion, household and politics dominated until 2003; however, later they were replaced by more practical subjects such as foreign languages, computer literacy, management, legal knowledge and others. These changes can be associated with the development of information technologies, changes in market requirements, and processes of internationalization and globalization that have significantly changed the requirements in labour market, the spectrum of human skills and, thus, learning preferences of adults.

\section{Foreign Language Policy in Lithuania}

Since 2004, when Lithuania joined the EU, "changes in social understanding of the importance of foreign languages in Lithuania have been strengthened by the processes of integration into the European Union and increasing globalization" (Bulajeva, 2007: 95). This, according to Bulajeva (2007), explains the growing 
interest and importance of foreign languages, which has become "an international tendency" (Bulajeva, 2007: 97).

Records provided in the Language Education Policy Profile (2004-2006) demonstrate the growing demand for foreign languages:

In relation to the entry of Lithuania to the European Union, the social demand for foreign languages, most of all English, has become stronger. In general the multilingual situation in Lithuania is not without dynamic tensions, due to demographic and historical factors and to the search for a just balance between the legitimate assertion of the state language, the full recognition of minority languages, and the growing demand for foreign languages. (The Language Education Policy Profile, 2004-2006: 2)

In A Survey of English Language Teaching in Lithuania: 2003-2004, several documents that can be considered as a solid base for foreign language policy in Lithuania are mentioned, i.e. The General Concept of Education in Lithuania (1992), the founding document which laid out four phases for the reform of the education system; The National Education Strategy (2003-2012), in which the status of foreign language instruction in the national education system remains prominent; The National Longterm Development Strategy (2002), where foreign languages are seen as an important social factor in the overall development of the country, and as a tool for the integration into the European cultural and economic sphere; and the Strategies in Foreign Language Teaching that aim at promoting awareness and highlighting the importance of language learning in a modern society, fostering foreign language educational initiatives such as textbook development, early learning, innovative teaching, and new assessment system, and maintaining cooperation between formal and non-formal education institutions in the field of language education (A Survey of English Language Teaching in Lithuania: 2003-2004: 22-23). Consequently, national directives are in concordance with the Common European Framework of Reference for Languages: Learning, Teaching, Assessment, a document issued by the Council of Europe in 2001. This document has remained a solid and significant ground for European and national foreign language policy.

In addition, issues related to foreign language education for adults are discussed in the Language Education Policy Profile (2004-2006), which demonstrates a growing interest and demand for adult education and foreign language learning in Lithuania; however, limited financial support from the state, lack of information about non-formal adult education and disregard of new options of lifelong learning hinder successful development of foreign language education of senior learners. 


\section{Conclusions}

The research helped to determine different factors that influence lifelong language learning:

(1) It has been found that self-concept and motivation are important issues in senior adult education. Stages of adult development and self-perception of the age help to foresee possible steps in lifelong language learning (LLL). Senior learners can be divided into three age groups: (1) from 55-65 years (citizens still actively contributing to the society); (2) from 65-75 (citizens, whose ambitions depend on their health, professional status and personal relations); and (3) 75 years and older (citizens, who begin to rest and tend to withdraw from an active social life). The first two groups, especially, can be considered as a potential target for the implementation of lifelong language learning.

(2) Senior citizens' attitudes towards age, self-confidence and willingness to contribute to the society are considered as significant factors for the implementation of the European policy of social integration.

(3) The analysis of the European citizens' understanding of age shows that 33\% of the respondents think that the age when one starts to be regarded as "old" is from 61 to 70 years. $24 \%$ of the European citizens think that "old" age starts from 51 to 60 years, while $16 \%$ of the respondents state that "old" age is from 71 to 80 years. In addition, the analysis of Baltic region countries shows that the youngest age when one starts to be regarded as "old" is in Germany (60.1 years), Latvia (61.5 years), Estonia (62.4 years) and Poland (62.8), while the "old" age in Denmark, Lithuania, Finland and Sweden starts from 64.3 to 66.6 years. This allows drawing a conclusion that the scope of lifelong language learning has been underestimated and needs to be seriously reconsidered in the nearest future.

(4) Successful development of adult education in Europe depends not only on senior citizens' personal attitudes to their age, but also on a variety of other factors. The analysis of trends of adult education in Europe shows that inadequacies in adult education policy on the national level, low public financial support, demographic changes, migration and personal obstacles to the participation in adult education are the main factors that hinder successful development of lifelong language learning.

(5) The survey of previously conducted research into Lithuanian adult education demonstrates that the main reasons motivating senior citizens to participate in adult education are higher requirements in labour market, opportunities for self-realization, increased possibilities of finding a job and motivation to meet new people.

The first-stage research into educational preferences of senior adult learners points to huge possibilities of lifelong language learning in Europe. The system 
of lifelong language learning has to be worked out in concordance with the set objectives for the development of multilingualism and fostering cross-cultural communicative skills.

\section{Summary}

Recent demographic changes in Europe (ageing, migration and others) demonstrate the importance of senior adult education - an urgent issue at both national and the European Union policy levels. Extended retirement age in the Member States of the EU is a big challenge in the process of employment of elderly people. Lifelong language learning (LLL) is equally important for both active, working-age citizens and for senior citizens of retirement age. The problem of the research is grounded in the challenges that many European societies currently face: the retirement age being extended, employees need to adapt to the changed working conditions and satisfy urgent demands of the market. One of the basic needs is to acquire or maintain multilingual skills, without which their status in the competitive market would become complicated. In many European countries, senior adult education is viewed as an integral part of the whole education system that is directed towards engagement of senior citizens into active social life, job maintenance, development of cross-cultural communicative and language skills and more diverse opportunities for self-realization. The aim of this research is to examine the current situation of senior adult language education in the EU. The following research objectives were set: to examine legislation system regulating senior adult education; to analyze statistical information, related to senior adult education and processes of lifelong language learning; to analyze different possibilities for the implementation of lifelong language learning in Europe. The research methods are as follows: content analysis (examination of the legislation, regulating senior adult education in EU countries) and quantitative analysis of statistical data from different EU countries. Many factors which directly influence the scope and organization of senior adult language learning demonstrate the need to re-evaluate the concept of lifelong language learning and set new objectives.

\section{Bibliography}

1. Adult education trends and issues in Europe. (2006). The European Association for the Education of Adults. Retrieved from http://ec.europa.eu/education/pdf/doc268_en.pdf

2. Aitchinson, W. (2004). A European Strategy for Linguistic Diversity and Language Learning. International Conference - Best Practices of Learning Less Widely-used Languages in Multicultural and Multinational Europe. Vilnius: Lietuvių kalbos instituto leidykla, 18-24.p.

3. Bulajeva, T. (2007). Introducing Early Foreign Language Teaching in Lithuania: Policies and Stakeholder Views. International Conference - Languages in Lithuania: Aspirations and Achievements. Vilnius: UAB "Ciklonas", 95-104.p.

4. Eurostat. (2007a). Obstacles to participation in education and training. Retrieved from: http://epp.eurostat.ec.europa.eu/statistics_explained/index.php?title=File:Obstacles_to_pa rticipation_in_education_and_training,_2007_\%281\%29_\%28\%25\%29.png\&filetimesta $\mathrm{mp}=20111117131345$ 
5. Eurostat. (2007b). Reasons for participation in non-formal education and training. Retrieved from: http://epp.eurostat.ec.europa.eu/statistics_explained/index.php?title=File:Reasons_for_pa rticipation_in_nonformal_education_and_training,_2007_\%281\%29_\%28\%25\%29.png\& filetimestamp $=20111117131421$

6. Eurostat. (2010). Lifelong learning statistics. Retrieved from: http://epp.eurostat.ec.europa.eu/statistics_explained/index.php/Lifelong_learning_statistic s\#Main_statistical_findings

7. Language Course Teaching Methods for Senior Citizens. (2006). [Grundtvig 1.1 - part of the European Commission's Lifelong Learning Programme]. The European Commission.

Retrieved

from: http://www.seniorlanguage.com/uploads/media/Microsoft_Word_Final_report_doc.pdf

8. Language Education Policy Profile (2004-2006). Švietimo ir mokslo ministerija and the Council of Europe. Retrieved from: http://www.google.lt/url?sa $=$ t\&rct $=\mathrm{j} \& \mathrm{q}=\&$ esrc $=$ s\&source=web\&cd=1\&ved=0CC0QFjA A\&url $=$ http $\% 3 \mathrm{~A} \% 2 \mathrm{~F} \% 2 \mathrm{Fwww}$. coe.int $\% 2 \mathrm{Ft} \% 2 \mathrm{Fdg} 4 \% 2 \mathrm{Flinguistic} \% 2 \mathrm{FSource} \% 2 \mathrm{FProfil}$ e_Lituanie_EN.doc\&ei=iqQXUd-

XG4GztAaLpICYCA\&usg=AFQjCNFbRzhkR3kd_LORBDTZVbFOQfdiA

9. Lietuvos suaugusiujų švietimo ir informavimo centras. (2009). Mokymosi visa gyvenima strategija. Požiūriu ịvairove. [Project]. Retrieved from: http://www.suaugusiujusvietimas.lt/modules/document_publisher/documents/3/MVGS_P oziuriu_Ivairove.pdf

10. Multilingualism: An Asset for Europe and a Shared Commitment. (2008). The European Commission. Communication from the Commission to the European Parliament, the Council, the European Economic and Social Committee and the Committee of the Regions. Retrieved from: http://ec.europa.eu/languages/pdf/comm2008_en.pdf

11. Socialinès informacijos ir mokymų agentūra. (2011). Taikomasis suaugusiujų švietimo tyrimas. Retrieved from: http://www.suaugusiujusvietimas.lt/lt/publikacijos/

12. A Survey of English Language Teaching in Lithuania: 2003-2004. Ministry of Education and Science of the Republic of Lithuania and British Council Lithuania. Retrieved from: $\mathrm{http}: / / \mathrm{www} . \mathrm{smm} . \mathrm{lt} / \mathrm{en} / \mathrm{stofedu} /$ docs/edu_reform/english\%20language\%20teaching.pdf

13. Teresevičienè, M; Zuzevičiūte, V. (2009). Towards the Professionalization of Adult Educator's Activities: Challenges and Perspectives. Kaunas: The Institute for International Cooperation of the German Adult Education Association.

14. TNS Opinion \& Social. (2012). Active Ageing. [Report - Requested by European Commission's Directorate General for the Employment, Social Affairs and Inclusion]. Retrieved from http://ec.europa.eu/public_opinion/archives/ebs/ebs_378_en.pdf

\begin{tabular}{|r|l|}
\hline $\begin{array}{r}\text { Prof. Dr. Ingrida } \\
\text { Žindžiuvienė }\end{array}$ & $\begin{array}{l}\text { Vytautas Magnus University, Kaunas } \\
\text { Lithuania } \\
\text { Email: i.zindziuviene@hmf.vdu.lt }\end{array}$ \\
\hline M.A., Austė Sruogaitè- & Vytautas Magnus University, Kaunas \\
Kuliešienè & Lithuania \\
& Email: auste.sruogaite- \\
& kuliešiene@fc.vdu.lt \\
\hline
\end{tabular}

